\title{
LEARNING MOBILITY CHALLENGING BORDERS: CROSS-BORDER EXPERIENCES OF EASTERN EUROPEAN IMMIGRANTS IN SPAIN
}

\author{
Silvia Marcu \\ Instituto de Economía, Geografía y Demografía \\ Consejo Superior de Investigaciones Científicas (CSIC) Spain \\ silvia.marcu@cchs.csic.es \\ C/Albasanz 26-28; 28037 Madrid; Spain
}

This article examines the cross-border mobility practices of Eastern European immigrants across and within European Union (EU) borders, taking into account the changes in the patterns of the EU border regime which have affected mobility in the last twenty years. Drawing on empirical research with references to in-depth qualitative interviews of Eastern immigrants in Spain, this article highlights the ways in which the emerging models of crossborder mobility management are producing new geographies of the EU border. On the one hand, (re)bordering makes human mobility difficult, while, on the other hand, networked bordering facilitates mobility. The conclusions confirm that the flexibility of the European border allows the mobility of people, and also indicate that, while crossing borders, Eastern Europeans learn about mobility and practice it as citizens of Europe.

Keywords: mobility, border, European Union, Eastern Europeans, Spain

\section{Introduction}

Cross-border mobility as expressed in temporary and permanent movement is an important element of post-communist restructuring in Eastern Europe. The two enlargements of the EU (2004, 2007), which incorporated twelve countries of Eastern Europe into EU structures, changed the map of mobility from the former region towards the EU, while offering a view of a Europe without borders (Meinhof 2002). These events favoured an increase in human mobility that, together with the convergence of communications and transportation, led to a new kind of movement, which is captured by Sheller and Urry $(2006,208)$ within the framework of the 'new paradigm of mobility'.

Authors have expressed concern about the ways of, and limits to, controlling mobility in the European social space by the EU and its member states, as well as the dynamics of territorial inclusion and exclusion raised by policy practice (Scott 2006; Bigo 2005; Verstraete 2001). 
This literature points to a 'fundamental contradiction between greater openness of internal borders and the reinforcement of controls at the external borders' (Foucher 1998, 242).

Closely related to these issues, the aim of this article is to analyse the experiences of Eastern Europeans engaged in labour mobility in Spain, in order to understand how EU enlargement has influenced the mobility of citizens and the manner in which they live and interpret crossborder practices. It aspires to contribute to the empirical study of human production and reproduction of borders as a way of understanding the persistence of borders and their meaning and implications for the European integration process. The article tries to capture how the EU operates with two sets of border regimes, which have far-reaching consequences for the re-territorialisation of borders on the continent. While inside the EU state borders have been bridged in the sense that they no longer represent physical obstacles to movement, the EU's external borders have become major barriers in terms of the movement of people (Scott and Houtum 2009).

Although borders have been recognized as an essential component of mobility, research in this area is largely lacking insight into migrants' own perceptions of migration and crossborder mobility; perceptions that this article wishes to explore.

First, the article looks at the relationship between cross-border migration/mobility and the enlargement of the EU towards the East. It highlights, on the one hand, how migration becomes mobility for Eastern European citizens following the policy of open borders in the enlarged EU, and, on the other hand, how the border remains a barrier to the free movement of citizens whose countries are not part of the EU. Thus, the article underscores the role borders play in human mobility by taking into account the EU policy of free circulation of people: border as network (opening up of borders under the Schengen Agreement and enlargement), and border as barrier (the bordering and re-bordering process). I attempt to continue Rumford's (2006) thesis by examining the mechanisms through which the EU 
constructs and reconstructs its borders with its close neighbours and how these processes are dynamic, contingent and sometimes contradictory.

Second, I analyse the importance that overcoming borders has for mobile citizens, while highlighting the nature of mobility between Eastern Europe and the EU. Focusing on the cross-border migration and mobility of various groups of immigrants, the article aims to shed light on the ways in which migrants and citizens construct their experience of mobility beyond the border. Using as reference the experience of people who have circulated between their home countries and Spain over the last twenty years, since the emergence of labour emigration from Bulgaria, Moldova, Romania and Ukraine, the article analyses whether borders are seen as an instrument for learning mobility or as an obstacle to current human mobility and advocates the right to mobility that people from non-EU countries have. Thus, the article concentrates on the opening of the internal borders within the EU and less so on its external borders.

My argument is that migrants have assumed their mobility through the challenge posed by the EU's policy changes in (re)bordering. They have to live with and learn to handle EU borders. Thus, the concept of mobility in the wider Europe highlights that in an ever increasingly mobile world, mobility may be a fundamental right that complements others (Recchi and Favell 2009). I argue for a rethinking of borders as mechanisms, not of division, but of connectivity. As Cooper and Rumford $(2013,108)$ noted, 'we need to view borders not simply as markers of division but also as a mechanism of connection and encounter'.

I refer to the mobility from Eastern Europe to Spain given that Spain has become the most attractive EU country for migratory flows over the last decade. As Arango (2013,2) argues, 'Spain is the second-largest recipient of immigrants in absolute terms among the Organization for Economic Cooperation and Development (OECD) countries, after the United States'. Given the restrictions throughout Europe, by the second half of the 1990s it was hard for 
Eastern Europeans to emigrate with a regular work visa. As such, the main option was to move irregularly. In this context, Spain (together with Italy) became a place of preference for the Eastern European networks that have arisen in recent years, coinciding with the opening of the Schengen border (2002) and EU enlargement to Romania and Bulgaria (2007). Despite the consequences of the economic crisis which have been widely attributed to the adverse developments in the construction sector, the mobility of Romanians and Bulgarians to Spain has continued to increase (Viruela 2011).

I have considered it appropriate to include Moldovans and Ukrainians in the sample, because their presence allows us to better interpret the ambivalence of borders: bordering versus networked border. The number of Moldovans and Ukrainians has increased in Spain 'because of the setting up of networks' (Stanek and Hosnedlova 2012, 65). Moreover, thousands of Moldovans and Ukrainians who live and circulate between their countries of origin and Spain make use of EU citizenship, something which allows them to circulate within the EU territory (Marcu 2009).

The article is organised as follows. First, I summarize the main theoretical concepts regarding cross-border mobility. After the explanation of the methodology used, I present a review of the border regime and the mobility of Eastern Europeans in Spain and the EU, focusing on the legislation regarding the free circulation of people from Eastern Europe. Subsequently, I analyse the perceptions of mobile citizens, considering three periods that mark the circulation of Eastern Europeans and that accompany several changes in border regime: the complete closure of borders; their partial opening; and finally, the EU enlargement which led to crossborder flexibility. The conclusions confirm that the flexibility of the European border facilitates the mobility of people, and also indicate that, while crossing borders, Eastern Europeans learn about mobility and practice it as citizens of Europe. 


\section{Cross-border mobility approach}

\section{Between (re)bordering and the networked border}

Recently, 'border studies have moved from the realm of the gradual construction of Europe as a polity to an increasing focus on social processes related to the (re-/de-)making of boundaries within and across national borders' (Jansen 2013, 37). Authors found two perspectives that have come to dominate the discussion on EU borders: on the one hand, securitized borders associated with the process of bordering and (re)bordering (Andreas 2003) and, on the other hand, borderless Europe -networked border- in which the barrier impact of borders became insignificant (Newman 2006).

Re(bordering) refers to challenging, expanding or altering the idea of Europe in order at once to accommodate Eastern Europeans, and potentially other neighbours, as new citizens of the EU, and to define its new spatial, cultural and conceptual boundaries (Paasi 2009; Wallace 2002). As action, (re)bordering includes the bureaucratic legal and police practices aimed at establishing a tight perimeter around the EU, while opening up the internal EU borders. Thus, (re)bordering, as I conceive it, is at once about inclusion and exclusion and its limits. Hand in hand with the opening of internal borders and the closing of external ones goes the more surreptitious process of introducing various forms of border controls within EU territory Balibar's 'ubiquity of border' (2002).

Another way to theorize borders in spatial terms is the idea of mobility and networked borders that asserts a particular network/border relationship. Borders and networks share a mutually constitutive dynamic, in the sense that localities are connected to 'larger' geographical spaces and scales in such a way that we have, as Dicken, Kelly, Olds and Yeung $(2001,97)$ sum up, 'a mutually constitutive process: while networks are embedded within territory, territories are, at the same time, embedded into networks'. One of the ways in which borders and networks interplay is the idea that borders are increasingly designed to embrace mobility not only in 
ways that render borders mobile in themselves, but also to the extent that some borders actually require mobility to be recognized as borders. This is particularly relevant in the EU countries, where the borders between member states are fluid and thus may not be recognized as borders in terms of their locality and function (De Gijsel and Janssen 2000).

The unresolved tension between ideas of networked Europe and (re)bordering has opened up the possibility of a more nuanced account of Europe's borders, in particular, an awareness that the EU's borders are becoming differentiated and can vary in scope and tightness (Hassner 2002). For instance, the EU's security borders are far more rigid than the equivalent economic, telecommunication and education borders, which are designed to facilitate rather than reduce mobility.

The bordering thesis cannot easily accommodate the differentially permeable borders of networked Europe. At the same time, the idea of a Europe defined by flows and networks downplays the importance of territorial bordering and the ways in which political priorities can result in some borders being more important than others: what was previously the EU border with Eastern Europe (along the line of the Iron Curtain) has become relatively unimportant when compared to the enlarged border with Ukraine and Moldova.

\section{Cross-border mobility as connectivity}

The twenty-first century is regarded as an era of mobility, fluidity, openness and connectivity. As Cooper and Rumford $(2013,108)$ stress, in this mobility era, 'borders are not generally considered to be by nature wholly divisionary'. They simultaneously delineate and connect an inside from its outside (Van Houtum, Kramsch and Zierhofer 2005). As Paasi (2009, 45) rightly points out, 'borders create 'channels' or 'conduits' of passage and in doing so provide a means through which facilitated connection, for some and not for others, takes places'. Related to this, Balibar (2002) and Bosniak (2006) state that the analysis of cross-border 
mobility reveals a great deal about the politics of mobility and its material dynamics, particularly through legislative regulations, the geopolitics of homeland 'security' and the embodied politics of identity and difference. In this context, security strategies have to be imagined on a global scale, as the trajectories of everyday mobility cannot easily be contained inside state borders (Cresswell 2010; Hannam, Sheller and Urry 2006). King, Skeldon and Vullnetari $(2008,2)$ argue that 'the distinction between internal and international moves becomes increasingly blurred, not only because of geopolitical events and the changing nature and configuration of borders, but also because migrants' journeys are becoming increasingly multiple, complex and fragmented'. This is relevant in the case of cross-border mobility at the Romanian-Moldovan-Ukrainian border.

However, as a result of the new choreography of the border opening, transnationalism has emerged as a cross-border field where migrants on the move for opportunities of work, try to be continuously between here and there (Glick Schiller, Basch and Blanc-Szanton 1992; Portes, Guarnizo and Landolt 1999) and play an active role in shaping 'transnational space' (Hannerz 1996). Therefore, mobility and fluidity (Hannam, Sheller and Urry 2006) permit the connectivity across EU borders (Rumford 2007), interdependency or dependency on economic pressures, geographical proximity and the impossible task of the EU insulating itself from its neighbours.

\section{Cross-border mobility as feelings: a people approach}

Van Houtum $(1999,330)$ noted that 'not only the objective reality of the borders is important, but also the subjective reality, the feelings, actions and thoughts of the actors confronted with the borders'. This is a people approach (Van Houtum 2000) and concentrates on the interaction or the lack of interaction between people on both sides of border. 
Thus, the cross-border mobility of Eastern Europeans can also be seen as a mental learning process that starts in the home country. The more one probes the essence of borders, the more it becomes apparent that there is nothing at all certain about them; they are those places that are known only by what we feel in their proximity. Yet, it is the emotional impact -the very thing that borders signify- that continued to be overlooked. The border is thereby divided not just in a spatial sense but also in a mental sense, and 'the force of the us-them effect feeds the mental distance in cross-border mobility' (Van Houtum 1999, 334). This approach is often used in border research in the EU, where many of the physical barriers have been removed and where the borders are moving forward in the direction of an integrated border. De Gisjel and Janssen $(2000$, 66) stated that 'mental distances play an important role in the European labour markets'. In turn, Van Houtum and Strüver $(2002,142)$ claim that overcoming borders and mental distance through Euro-regions involves the 're-imagining of the self versus the other'.

The focus of the people approach is on the emotional reactions, actions and origins of individuals confronted with cross-border mobility and how they learn to deal with the border through mobility. The concept of learning mobility, however, has scarcely been studied in the literature. Morokvasic $(2004,9)$ notes that 'cross-border mobility has a learning function' while Vertovec $(2007,5)$ states that 'once people learn how to cross borders they are less concerned with whether they go legally or not'.

If we want to better understand the configuration and characteristics of cross-border mobility we must include in the analysis the perceptions of people who practice it. In other words, how mobile citizens learn mobility, that is to say, their rights, their possibilities of crossing borders and the strategies they need to continuously adapt to changes in European policies. Thus, we have to interrupt dominant thinking and practice by displacing attention from borders to the crossers of borders themselves (Hyndman 2012). And this is what we are going to do here. 


\section{Methodology}

The research supporting this article was aimed at gaining a qualitative insight into the phenomenon of cross-border mobility in a wider Europe from the perspective of the movers themselves. From October to November 2010 and January to June 2011, I conducted 78 qualitative interviews with Romanian, Bulgarian, Moldovan and Ukrainian migrants working in Spain and who arrived in-country in three waves: 26 before the opening of the Schengen border, 26 after the opening, and 26 following the entry of Romania and Bulgaria into the EU. These three variables formed the primary recruitment criteria, although it was also envisaged that there would be differentiation amongst respondents based on variables such as country of origin, age, family situation and reason for moving. This article is based on the combined responses from individuals from the four main groups and provides an overview of the key issues identified in the study.

The interviews were carried out in the Community of Madrid and the Community of Valencia, as they record the most important Eastern Europeans flows in Spain: 78 in-depth interviews of working-age men and women in the following order: 32 Romanians, 20 Bulgarians, 14 Moldovans ( 7 of whom had Romanian citizenship) and 12 Ukrainians (4 of whom had Polish citizenship). In order to add a cross-border element to the empirical work and to gain a greater understanding of the complexities related to border experience, during April and May 2011, further qualitative interviews were carried out in Romania, Moldova and Ukraine with returning mobile citizens who had moved to Spain but had since returned to their country; 10 in-depth interviews were conducted along the border situated between Romania and Moldova at Giurgiulesti and Albita, and 10 more in Cernauti - on the border between Romania and Ukraine. In addition, we interviewed two bus drivers who travel regularly on routes between Ukraine and Spain and Romania and Spain. 
Regarding analysis, grounded theory methodology $y^{\underline{1}}$ (Glaser and Strauss 1967) was used. The analysis of the information from the standpoint of codes, concepts, and categories ${ }^{2}$ identified key relations between the data obtained and conclusions reached (Charmaz 2000). According to the principles of theoretical sampling theory, data analysis began with the first interview and continued throughout the interviewing process (Glaser and Holton 2004). This research, in striving to apply a genuinely interdisciplinary methodology, drew upon people's approach to the cross-border mobility process, and concepts such as 'learning mobility', '(re)bordering' and 'networked border', all of which span different disciplines with the aim of developing a more holistic understanding of the status of cross-border mobility of Eastern European citizens. The study thus examines three periods of Eastern European migration in Europe and Spain: the first period (1992-2002), when the border was closed to all of the immigrant groups studied; the second period (2002-2007), when the Schengen Agreement allowed the opening of the border for Romanians and Bulgarians for a period of no more than 3 months, but not for Moldovans and Ukrainians; and the third period which has continued since started in 2007 upon the opening of the EU towards Romania and Bulgaria, which allowed their citizens free circulation without time limits, although until 2013 there were restrictions in the labour markets in Spain and other European countries ${ }^{3}$. From 1 January 2014, however, Romanian and Bulgarian citizens are able to fully exercise their right to work in Spain and in all EU countries without a work permit (European Commission 2014).

In the case of Moldovans and Ukrainians, an EU norm was imposed, which requires entry visas for their citizens who wish to enter EU territory.

As Scuzzarello and Kinnvall $(2013,93)$ rightly point out, 'boundaries, as narratives, have an ontological dimension. People use causal narratives to make sense of their position in the world and through this, they construct their experiences'. Thus, in this article, I focus my empirical analysis on narratives produced by migrants. 


\section{Mobility and border regime of Eastern Europeans in the EU and Spain}

After the fall of communism in 1989, the first stage of migration from Eastern Europe to EU countries is framed by the years 1990 and 2002, a period characterised by bordering and thus requiring entry visas for the four migrant communities to reach Spain.

From 1990-1991, the main reasons for emigration were ethnicity (with significant flows of Romanians to Germany, Hungary and Israel, and of Bulgarians to Greece and Turkey) and business (small-scale border trade). However, from 1991-1992, the unstable economic and political situation meant that migration from Eastern Europe to EU was for economic reasons. This was an era of exploration and a search for job opportunities that Eastern Europeans were undertaking for the first time, as a result of the harshness of the communist regimes in Eastern Europe. Certainly, as Michalon and Nedelcu $(2010,8)$ rightly state, for Romania, 'during the dictatorial regime, in addition to the forced political migration, other forms of migration were performed, such as ethnic migration authorized by the communist government, migration of workers enrolled in programs regulated by the State, or student migration of the communist nomenklatura allowed to study outside their country'.

The intensity and destination of the Eastern European flows have varied from country to country. While Romanian and Bulgarian migrants were oriented from the early 90 s to the EU countries, Ukrainian migrants followed their historically established corridors: inhabitants of Western Ukraine followed the route to the European Union, while those from Eastern Ukraine chose the Russian Federation. In turn, Moldovan migrants were directed towards the Russian Federation (for the Russian-speaking population), and Romania, Italy and Spain (particularly for Romanian speakers) (Marchetti and Venturini, 2013).

For the four group of migrants studied in this article, between 1990 and 1995, there was temporary labour migration towards the EU with a lower rate of annual migration. In the Romanian case, as Sandu (2006, 23) explains, 'the emigration rate from Romania to the EU 
countries was around 3\%'. However, especially from 1996 onwards, Eastern Europeans' (almost all Romanians) international routes for work converged towards the southern region of Western Europe, with Italy and Spain being the main destinations. According to Sandu (2006, 25), 'between 1996 and 2001, the rate of Romanian emigration towards EU countries was around $7 \%$ '.

At the end of 2001, there were 52,971 Romanians, 23,707 Bulgarians, 2,776 Moldovans and 20,267 Ukrainians in Spain. ${ }^{3}$ Since 2000, Spain had agreements with Romania ${ }^{4}$ (2001), Bulgaria (2003) $)^{\frac{5}{-}}$ and Ukraine (2009) $)^{\frac{6}{}}$, which regulated migration flows from these countries to Spain, with direct implications for the prevention of irregular migration and the labour exploitation of workers.

The second stage of mobility, between 2002 and 2007, was marked by the opening of the EU borders to Romania and Bulgaria. The elimination of the Schengen visa requirement promoted a rapid growth in circular migration, even to the extent that Romanians and Bulgarians who had previously been 'stranded' in Schengen countries were able to return to their countries. With the possibility of a legal three-month tourist stay, a sophisticated circular migration system developed, focused primarily on Italy and Spain. 'While its previsions liberalise cross-border flows of people and goods inside the EU, they also reinforce the barrier function of the EU's external borders' (Meinhof 2002, 1).

In order to make the border flexible, EU countries such as Romania and Poland granted Romanian or Polish nationality (therefore, EU status) to Moldovans and Ukrainians 'who could prove ethnic and family ties' (Marcu 2009, 417). In December 2007, Poland established a Polish Charter ${ }^{7}$ which can grant some rights of Polish citizenship to people of Polish descent who do not have Polish citizenship and who reside in Eastern Europe (Ukrainians, Moldovans and Belarusians). 
In Romania, the 1991 Law on Romanian Citizenship ${ }^{8}$ provides the possibility of possessing dual citizenship by allowing the restoration of Romanian citizenship to former nationals. 'The main beneficiaries of the law are the inhabitants of the former Soviet Socialist Republic of Moldova and the provinces of Northern Bukovina and Southern Bessarabia, in Ukraine' (Marcu 2009, 416).

Spain, as a host country, employed Eastern European workers in the irregular labour market. According to sources at the Spanish Ministry of Employment and Social Security, the number of Eastern Europeans increased in Spain, reaching the following levels at the beginning of 2007: 603,889 Romanians, 120,581 Bulgarians, 11,551 Moldovans, and 69,376 Ukrainians9 . Furthermore, during that period, Spain was experiencing substantial employment growth. Most of the growth took place in the construction sector and related services and manufacturing, as well as in the tourism sector. The incorporation of women into the labour market was significant at this time; this also increased the demand for household services, which migrants provided at lower wages. In addition to these initial effects, the network effects are also key to explaining the larger migrant flows observed in subsequent years (Viruela 2011).

The third stage of mobility (2007) began with the enlargement of the EU to include Romania and Bulgaria. However, when in December 2007 the Schengen area was enlarged by nine new member states, it was accompanied by further (re)bordering of the external borders of the EU. Hence, while new member states can finally enjoy the benefits of being part of the Schengen Agreement, their neighbours in the immediate vicinity once again feel the negative consequences of being only a neighbour. After their accession, Romania and Bulgaria encountered temporary restrictions in the EU labour market. The overall transition period of seven years is divided into three distinct phases ('2-plus-3-plus-2'). Different conditions apply in each phase. The national law of the other member states regulates the access of workers 
from Bulgaria and Romania to their labour markets in the first two years. Member states can extend their national measures for a second phase of another 3 years upon notification to the Commission before the end of the first phase; otherwise, EU law granting free movement of workers applies (European Commission 2011).

Between 2007 and 2009, Spain imposed a moratorium that prevented Romanians and Bulgarians from freely entering the labour market. Despite the fact that after 2009 Spain lifted the moratorium and allowed free circulation of Romanian and Bulgarian workers, in 2011, due to the severe economic crisis in Spain and the incessant flow of Romanians $(861,584$ registered, $30 \%$ of whom are unemployed and $15.7 \%$ inactive), the European Commission ${ }^{10}$ approved a temporary measure (Order PRE2072/2011) that restricted the right to employment for Romanians who emigrated to Spain as of that date.

Despite measures to restrict labour and Spain's current acute economic crisis, the number of Romanians continued to grow, reaching a total number of 925.140 people registered in $2013^{11}$. The restrictions were lifted on January 1, 2014, and from this date, Romanians have the right to work in Spain (European Commission 2014).

Similarly, there was an increase in the number of Bulgarians to $171,769^{12}$. The main receiving country of Bulgarian nationals in the EU-15 is Spain, which attracts about $40 \%$ of those wishing to live and work abroad (Bogdanov and Rangelova 2012).

Although the strategy of obtaining Romanian or Polish nationality had been used since the 90s, after the entry of these countries into the EU, Poland in 2004 and Romania in 2007, the number of Moldovan and Ukrainian citizens with EU citizenship has increased considerably. In 2013, Spain had 16,758 Moldovans, 1,391 of whom are citizens of the EU, as well as 80,784 Ukrainians, 5,957 of whom are members of the EU ${ }^{13}$.

\section{Crossing the closed border}


During the first period, Eastern European migration to Spain was 'highly dependent upon passports, visas, residence permits and labour qualifications' (Urry 2007, 10). There are several broad stages that respondents went through when planning their move: the decision to move, the trajectories, waiting for approval and confirmation that the move would take place. Thus, the ways in which these stages manifested varied according to the context of people's moves: moving with a relative; moving independently; moving with family; or moving for a longer period of time (Van der Velde and Van Naerssen 2011).

Regarding the laws that are applied equally to the citizens of the four countries represented in the first stage of mobility, during this period there were few differences between the trajectories of Eastern Europeans. Emigrants resorted to the strategy of irregular immigration by means of falsifying passports, or trips as tourists. Interviewees' discourse is structured around memory, which concerns mainly the reasons for their departure:

In Romania, I was nobody; so I said 'no' to Romania. (Female, age 52, Romania, first arrival in Spain 1993)

Bulgaria was a black hole of corruption and unemployment. (Male, age 50, Bulgaria, first arrival in Spain 1994)

Voices are torn and become diluted in their memory. As Maria remembered:

I had a three-year-old daughter and a 17-year-old son who wanted to study, and I was very embarrassed that I could not help my children nor buy food. It was difficult, because it was as if life had stopped: there was no work, so I decided to leave. (Female, age 52, Ukraine, first arrival in Spain 1995)

The main causes of the decision to move from Eastern Europe to Spain are of an economic nature, including a desire for higher income potential and better working conditions. The interviewees told me they had travelled or obtained visas for other countries within the 
Schengen territory, but it was impossible to settle in them, because they did not know the language. However, as Ioana noted:

I learned a little Spanish by watching romantic television dramas. (Female, age 48, Romania, first arrival in Spain 1996)

None of the interviewees from this first stage obtained an entry visa through the Spanish consulates. As Ovidiu remembered:

Someone I knew in Bucharest arranged things for me. It took some time to obtain the visa since I started in March and I got it on 30 November. (Male, age 49, Romania, first arrival in Spain 1992)

The expressions of interviewees reflect the remembrance of the anguish they experienced while going through the procedure of obtaining a visa, as well as the moment of crossing the border. All of them travelled through other European countries in order to reach Spain. As Ion explained:

There was a travel agency there that organised trips to France. I left Romania, went to the Czech Republic and then France. From there I took a taxi and got to Spain with two Romanian friends. Since I only had a visa for France, once I left that country, I was illegal. (Male, age 52, Romania, first arrival in Spain 1996)

Ukrainians have experienced travelling to various European countries, such as Austria and Germany. As Olena confessed:

In Ukraine if you have money you can get the type of passport you want and you can go where you like. You can only go to Russia with your real passport... There are travel agencies you pay your money to and they take care of everything. For me, my arrival cost about USD\$500. (Female, age 48, Ukraine, first arrival in Spain 1999)

In turn, Moldovans emphasise the misfortunes they suffered and the money lost in their attempts to acquire visas. As Dorina noted: 
They sent me an invitation, but it turned out to be fraudulent. They did not admit me, and I had to find an intermediary: someone who would help me. But it cost me a lot of money, and it turned out that a poorly-made passport was sold to me. Then, I got a travel agency to arrange for my exit. Altogether, I think I spent more than $€ 2,000$ to leave. (Female, age 45, Moldova, first arrival in Spain 2001)

Nonetheless, all of them note the relative flexibility shown by Spanish border guards upon entry via road or rail. As Valeriu explained:

But upon entering Spain, it was different. Fear came upon me later, because I didn't have papers; upon arrival they allowed me to enter. (Male, age 50, Moldova, first arrival in Spain 1999)

Still, since 1990, the former Iron Curtain has been gradually replaced by paper-wall (re)bordering, consisting of visas, invitations or declarations (Pijpers and Van der Velde 2007). Yet, the eagerness to learn reflexively from experiences of the first stage of mobility, using up-to-date expertise, greatly helps in finding ways to circumvent paper walls.

\section{Between networked border and (re)bordering}

In this stage, we witness the opening of the EU borders, which facilitated the mobility of people. Romanians and Bulgarians received a green light to circulate for a period of three months within the Schengen territory, and both Moldova and Ukraine were now on the road towards entering the EU. In fact, there is tension between accounts of the openness of borders, and accounts which draw attention to processes of securitized bordering (Rumford 2006, 156). Thus, we refer here to two categories:

1) The first category comprises Romanians and Bulgarians who had the support of European laws regarding the opening of the Schengen region. Respondents brave the borders despite 
knowing that they cannot travel if they cannot show that they have enough money to meet their daily expenses during their stay in Spain. As Vasile recognized:

We came as tourists, in a bus with 47 people, from Mures; we had to show that each of us had $€ 700$ in order to prove that we could travel in Spain. (Male, age 40, Romania, first arrival in Spain 2002)

In contrast to the first stage, when people did not know exactly where their journey would end, during this stage they travelled to a destination where they knew that a relative, friend or acquaintance was waiting. During this period, the first networks created in the 1990 s were expanded, while there was a parallel process of family reunification on a grand scale (Viruela 2011).

For Romanians and Bulgarians, circumstances changed: migrants were gradually transformed into citizens who circulate. Upon arrival in Spain, they tended to settle themselves more easily into the receiving culture. Because of the ties that they maintain with their home countries and the ease of travel, they were able to create a kind of fluidity of movement. It is here that transnationalism and the creation of a transnational social space (Faist 2000) allow citizens to move and learn to live with the border. Both turbulence and insecurity remained, since Romanians and Bulgarians could only stay for three months in Spain and at the border there were continual demands for money, whether to prove that they could afford the cost of maintaining themselves in Spain, or from corrupt bus drivers and border guards (International Labour Organization 2006). Spanish law supported the mobility process with the extraordinary measure taken in 2005 , when more than 600,000 people's status was legalised; a great number of these were from Eastern Europe (Ministry of Employment and Social Security 2005). In fact, some $30 \%$ of those interviewed obtained their papers in Spain because of this extraordinary legalisation process (Viruela 2011). 
Turbulence along the border varies according to the country of origin, type of transport and customs, which are linked to all sorts of traps and deceptions of bus drivers. As Ivan told us: I came on the bus one week; it was hard because the driver had trouble in some tunnels. We got on the bus...they asked us for money to repair the bus; it was a journey for madmen. When I arrived, my legs were numb and swollen... (Male, age 37, Bulgaria, first arrival in Spain 2003)

2) The second category comprises the Moldovan and Ukrainian interviewees; although they are still confronted with securitized borders, their experiences changed. If at first they hid their faces upon presenting their passports, they later took advantage of their experience and, with emboldened courage, discovered themselves and defied borders. As Natalia confessed: I left Donetk with a group. For three days I was in Austria and then I arrived in Venice where I broke off from the group, took a train and went to Milan until finally reaching Madrid. I had a six-day visa and while I was on the train, the police came on board at night at the borders. They put a torch in my face, so I got angry with them and they left me alone and asked no further questions. In any event, this was the second time I had crossed the border and I had already learned how to do it. (Female, age 44, Ukraine, first arrival in Spain 2004)

Here, the emphasis is not placed on the physical line, but on the mind-set and mental binding of the human actors that practice mobility. Following Gielis (2009), for these migrants the border between the former and the current country of residence is not situated around their lives, but has moved to the centre of their lifeworld.

Those who have managed to obtain European citizenship highlight the difficulties, but in that stage, they learn new strategies and how to travel alone, and blend in with the receiving society in order to be unnoticed, if necessary. As Victoria explained:

I went by bus to Budapest, and there I took a train to Milan and stayed a night in a hotel; there I took another train and changed trains five times. My friends told me: it is better for 
you not to join anyone because then they will know by sight that you are from Eastern Europe and they will stop you, they will interrogate you and examine the documents with more care. So I travelled alone and I came to Madrid where they were waiting for me. (Female, age 35, Moldova, first arrival in Spain 2004)

During this period, Ukrainians came to Spain by bus, because the market in the cities for the sale of false passports increased. By failing to adopt biometric passports, in order to legally acquire a Schengen visa, the number of documents required in Ukraine is high (between 9 and 21); according to those interviewed, it is very difficult to obtain a visa.

During this phase of mobility, there were people who purchased visas on the black market to travel to Spain by automobile or train. They talked about the bribes they needed to pay to customs agents when their hard-earned cash was found on them during return trips home. Respondents explained how one can circumvent the border regulations and overstay the visa without running into trouble by altering the passport stamp, having the passport illegally stamped or purchasing forged documents. As Yuriy admitted:

I crossed the border with a fraudulent passport purchased in Kiev. My wife and I, we took a bus. We were afraid, because there is a risk and, besides, you pay a lot of money. (Male, age 46, Ukraine, first arrival in Spain 2003)

One interviewee, a bus driver who runs the Spain-Ukraine route, told us that the process for obtaining a Schengen visa for Ukrainian professional drivers to be able to enter Spain is quite complicated. They are required to show many documents and are interviewed several times. Altogether, the wait is more than 70 days. On certain occasions, the consulate may 'delay cooperation' with the businesses without explanation. The visas are granted for one or more entries. In general, first-time visa applicants are granted only one entry. After making several requests, the validity of the multiple-entry visa is extended to several months or as much as a year, while its price ranges from $€ 40$ to $€ 90$. According to the International Labour 
Organisation report (2006), in 2004, a group of Eastern European countries (Moldova and Ukraine among them) presented their technical notes to the Working Group on highway transport of the Committee on Domestic Transport of the Economic Commission of the United Nationals for Europe (CEPE). The notes dealt with the problems the members of their transport industry faced in obtaining visas for professional drivers.

\section{Learning Mobility}

In this third-stage, for the Bulgarians and Romanians who were interviewed, for the most part, the border is unnoticed. Crossing it has become a journey, a change in venue. As Sorin noted: ...Like when you go on vacation, even though you are going away to make a life. (Male, age 24, Romania, first arrival in Spain 2009)

They leave their countries in search of professional opportunities and they no longer consider themselves immigrants but rather European citizens who have the right to circulate as well as study and work in Europe.

The respondents mentioned the economic implications of border lifting. As Diana explained: Can you imagine how much money we Romanians now put in savings? Well, when my father left, it cost him more than $€ 1,000$ to leave Romania, but for me it costs nothing: only the flight ticket. (Female, age 32, Romania, first arrival in Spain 2008)

Some mention the change encountered at the borders on their multiple trips taken since the fall of the totalitarian systems. As Yavor remembered:

In past years, they were closed, and if you had your papers in order and came to Spain, you would have to go to the non-EU queue, where they looked at your document with a microscope and appeared to overdo the enforcing. But now, everything is free: you pass through with your identity document. (Male, age 47, Bulgaria, first arrival in Spain 2000) 
After 2007, with the entry of their countries into the EU, Romanians and Bulgarians travelled less often by bus and more often by air, making use of low-cost airlines such Air Blue. The air routes multiplied for the biggest cities in Romania and Bulgaria to Spanish cities where there were the greatest number of Romanians and Bulgarians. As Viorica explained:

The airliners resemble Romanian trains of the Communist era because many people are standing; in the aisles there are children crying and a great deal of luggage bearing Romanian and Spanish products. (Female, age 29, Romania, first arrival in Spain 2010)

We find ourselves facing a panorama wherein there is intense movement; a panorama in which mobility is practiced. Romanians and Bulgarians place themselves in the culture of mobility, which is facilitated by the use of the Internet and mobile telephone. As Bogdan mentioned:

Now we no longer emigrate; we are simply moving when we wish to do so, because if I want to go to my country on a Monday, I can even buy my airline ticket on Sunday night on the Internet. (Male, age 29, Romania, first arrival in Spain 2007)

Furthermore, immigrants from Romania and Bulgaria have experienced upward mobility; they have settled themselves and their families in Spain and had children while in Spain. These citizens have become integrated into the local structures, which are reflected in their social networks. The development of immigrant networks, coupled with the creation of an important number of associations, Orthodox Christian and Adventist congregations, or other cultural centres, has developed immigrants' ties to their countries of origin, while also exposing their countries to the cultural values of Spain (Viruela 2011). As Guarnizo (2003, 715) notes, 'corridors of mobility and transnational economic and social activities' were created.

The Moldovans and Ukrainians who have European citizenship comment on the flexibility of the Spanish frontier in comparison to other European borders. As Nataliya reflected: 
Things are good in Spain. I got married and burned the miserable false passport... now the borders are open to me. (Female, age 25, Ukraine, first arrival in Spain 2009)

Ukrainians continue to come to Spain, for the most part, as tourists and with false passports that were acquired in the passport market in Kiev or Odessa. The drivers who were interviewed mentioned the level of corruption along the borders of the EU, given that they paid an average of $\$ 50$ in order to avoid delays along the Ukraine/Hungary border, which was for military, health and customs control, or related to the stopping place. If we had not paid, they would not have let us pass. (Driver on the Ukraine/Hungary border)

However, among the interviews we had with returning Moldovans, we observed that their discourse appears to show some hope. Mariana noted that:

I am now in the last phases of receiving a Romanian passport, so I will return legally. (Female, age 32, Moldova, first arrival in Spain 2008)

However, there is also desperation, since, as Sergiu suggested:

In Moldova nothing works, there is no help and, besides, it is not easy to settle down in Europe even if you do have help. How much help do you need when you have no rights? (Male, age 32, Moldova, first arrival in Spain 2010)

Interviewees claim that it would be good to lift the border with Romania so that all its residents may circulate and not only those who have Romanian citizenship. As Vitalie reflected:

Borders are in our mind, borders anger people and it is best that people should move and learn, and then return. (Male, age 28, Moldova, first arrival in Spain 2010)

They recognise that they have violated borders. As Ion concluded: A person, if necessary, will jump over walls to survive. (Male, age 40, Romania, first arrival in Spain 2007) 
Thus, as Van Houtum $(2000,60)$ rightly points out, we note 'a mental dimension of crossborder mobility, that places the process and the influence of the construction and reproduction of borders on behaviour at the centre of the analysis'.

\section{Conclusions}

This article highlights the importance of borders in terms of the mobility practiced by Eastern European migrants, from the perspective of the movers themselves, who over the last twenty years crossed EU borders and came to Spain seeking a better way of life. We argue that in the enlarged EU two perspectives of cross-border mobility are emerging: (re)bordering and networked border and connectivity. We find that from both perspectives there is a need for conceptual development and mutual engagement, and in this way, the people approach could be an important linkage between them.

Firstly, we have looked at the relationship between cross-border migration/mobility and the enlargement of the EU towards the East and have highlighted the role of the opening of the border in human mobility. We have seen how borders represent an instrument for learning mobility rather than an obstacle to modern human mobility. This is proved by the fact that the more borders are overcome, the more provisions for mobility are acquired. We confirm that the ability of individuals to manage border can modify a particular image of migration. Thus, the gradual opening of EU borders and the free movement of Eastern Europeans entwined in their constant interaction shape the mobility experience.

Secondly, the sample reveals that the flexibility of European borders facilitated human mobility coming from Eastern Europe. We can observe a change in the way that Eastern Europeans perceive borders while being on the move: while emigrants of the first stage had to confront borders as a matter of necessity and those of the second stage of mobility (with the support of transnational networks they found in the host country) had to live with borders, 
those of the third stage learn about mobility and practice it as citizens of Europe. Therefore, mobile citizens live not only with state borders but also with various other kinds of borders, such as mental and symbolic ones (Van Houtum 1999). Thus, the concept of border is not an enemy of mobile citizens, but rather has become a 'friend' who enriches our understanding of the complexities and ambivalences of movers' in-between lives (Recchi and Favel 2009).

It has also been found that while the experience of crossing borders became merely a trip for Romanians and Bulgarians as of 2002, and especially as of 2007, for Moldovans and Ukrainians it remains a challenging apprenticeship. After two subsequent rounds of Eastern enlargements, the EU now borders Moldova and Ukraine, and the idea of negotiating a visafree liberalisation regime with the EU has become one of the most important objectives of Moldovan and Ukrainian authorities.

Finally, in the wider EU, human mobility will help cross-border liberalisation, because mobility has the ability to liberate localities from central authority and encourage new dynamics of connectivity in such a way as to confound both core/periphery expectations and conventional models of growth and competitiveness. Thus, following Rumford (2007), borders and border crossings constitute an instrument for learning mobility, identity construction, self-actualization and sense of belonging.

In order to live in multiple communities people must be comfortable with and adept at crossing and re-crossing borders. Therefore, the flexibility of the European border facilitates the mobility of people, and also indicates the fact that, while crossing the borders, Eastern Europeans learn about mobility and practice it as citizens of Europe.

Thus, on the one hand, more work needs to be undertaken to explain the variation in particular states' approaches to the regulation of practices, speech and other embodied forms of crossborder mobility. As D'Andrea, Chofli and Gray $(2011,157)$ argue, 'by attending to the empiric-conceptual mediations, the process of investigation of mobility phenomena can be 
positively rethought'. While, on the other hand, there needs to be a greater level of dialogue between scholars of mobility and scholars of border. An integrated approach in mobility research could help to highlight broader global trends in cross-border mobility. Therefore, we should look more frequently into the discourse of mobile people in order to interpret how they learn mobility while crossing borders in an ever changing world.

\section{Notes}

1. A method that starts with the collection of data and, by means of the data collected, the codes from which the information is then extracted are detected. The codes are grouped into similar concepts from which categories that represent the basis for formulating a theory or hypothesis of reverse engineering are formed.

2. The interviews were coded and analysed with the Atlas ti (version 6) qualitative analysis programme.

3. Ministry of Employment and Social Security.

http://www.empleo.gob.es/es/estadisticas/index.htm

4. Agreement between Spain and Romania concerning the regulation and management of labour migration flows. Madrid, January 23, 2002.

http://noticias.juridicas.com/base_datos/Laboral/a191102-rum.html

5. Agreement between Spain and Bulgaria concerning the regulation of labour migration flows. Madrid, October 28, 2003.

http://ipv4.noticias.juridicas.com/base_datos/Laboral/a051103-aex.html

6. Agreement between Spain and Ukraine concerning the regulation of migration flows. Madrid, May 12, 2009. http://www.otrosi.net/article/acuerdo-espa\%C3\%B1a-ucraniarelativo-la-regulaci\%C3\%B3n-de-flujos-migratorios

7. Polish Charter was established by an act of the Polish Parliament dated 7 September 2007 and called the Act on the Pole's Card (Dz.U. 2007 no. 180/1280), which specifies the rights of the holder of the Card, the rules for granting, loss of validity and rescission of the Card, and the competencies of the public administration's bodies and procedures in these cases.

8.Romanian citizenship Law 21/1991, Romania, 1991.

http://www.romanianpassport.co.il/english/romanian-citizenship-law/

9. Ministry of Employment and Social Security, Spain, June, 2007.

http://www.empleo.gob.es/es/estadisticas/index.htm

10. European Commission (2011). Decision to Authorise Spain to Temporarily Suspend the Right of Free Circulation for Romanian workers (Regulation 492/2011) Brussels. 11.8.2011 C (2011) 5896 final.

11. Ministry of Employment and Social Security, Spain, June 30, 2013

http://extranjeros.empleo.gob.es/es/Estadisticas/operaciones/concertificado/201306/Residentes_Tablas_PR_30062013.pdf

12. Ministry of Employment and Social Security, Spain, June 30, 2013

http://extranjeros.empleo.gob.es/es/Estadisticas/operaciones/con-

certificado/201306/Residentes_Tablas_PR_30062013.pdf

13. Ministry of Employment and Social Security, Spain, June 30, 2013 
http://extranjeros.empleo.gob.es/es/Estadisticas/operaciones/con-

certificado/201306/Residentes_Tablas_PR_30062013.pdf

\section{References}

Andreas, P. 2003. "Redrawing the line: borders and security in the twenty-first century." International Security 28(2): 78-111.

Arango, J. 2013. Exceptional in Europe? Spain's experience with immigration and integration. Migration Policy Institute. Accessed March, 27, 2013 http://www.migrationpolicy.org/pubs/TCM-Spaincasestudy.pdf /.

Balibar, E. 2002. “What is Border?” Politics and the Other Scene. London: Verso.

Bigo, D. 2005. "Frontier controls in the European Union: who is in control?" In Controlling frontiers: free movement into and within Europe, edited by D. Bigo and E. Guild, 49-69. Aldershot: Ashgate.

Bogdanov, G., and R. Rangelova. 2012. "Social Impact of Emigration and Rural-Urban Migration in central and Eastern Europe." Final Country Report. European Commission.

Bosniak, L. 2006. The Citizen and the Alien. Princeton, NJ: Princeton University Press.

Charmaz, K. 2000. "Grounded Theory, Objectivist and Constructivist Methods." In Handbook of Qualitative Research, edited by N. Denzin and Y. Lincoln, 509-535. Thousand Oaks, CA: Sage. 
Cooper, A., and C. Rumford. 2013. "Monumentalising the Border: Bordering Through Connectivity." Mobilities 8(1): 107-124.

Cresswell, T. 2010. "Towards a politics of mobility." Environment and Planning D: Society and Space 28(1): 17-31.

D’Andrea, A., L. Ciolfi, and B. Gray. 2011. "Methodological Challenges and Innovations in Mobilities Research.” Mobilities 6 (2): 149-160.

De Gijsel, P. D., and M. Janssen. 2000. "Understanding the Dutch-German cross-border labour market: are highly educated workers unwilling to move?" Tijdschrift voor Economische en Sociale Geografie 91(1): 61-77.

Dicken, P., P. Kelly, K. Olds, and H. Yeung. 2001. "Chains and networks, territories and scales: towards a relational framework for analysing the global economy." Global Networks 1(2): 89-112.

European Commission 2014. End of restrictions on free movement of workers from Bulgaria and Romania. Accessed January 12, 2014 http://europa.eu/rapid/press-release_MEMO-141_en.htm?locale=en $/$.

European Commission 2011. Report from the Commission to the Council on the Functioning of the Transitional Arrangements on Free Movement of Workers from Bulgaria and Romania (SEC 1343 final) Brussels, COM(2011) 729 final. 
Faist, T. 2000. "Transnationalization in international migration: implications for the study of citizenship and culture." Ethnic and Racial Studies 23(2): 189-222.

Foucher, M. 1998. “The geopolitics of European frontiers.” In The frontiers of Europe, edited by M. Anderson and E. Bort, 235-250. London: Pinter.

Gielis, R. 2009. “A Global Sense of Migrant Places: Towards a Place Perspective in the study of Migrant Transnationalism.” Global Networks 9(2): 271-287.

Glaser, B.G., and J. Holton. 2004. "Remodelling Grounded Theory." Forum: Qualitative: Qualitative Social Research 5(2). Accessed December 15, 2013 http://www.qualitativeresearch.net/fqs-texte/2-04/2-04glaser-e.htm /.

Glaser, B. G., and A. L. Strauss, 1967. The discovery of grounded theory: strategies for qualitative research. New York: Aldine.

Glick Schiller, N., L. Basch, and C. Blanc-Szanton. 1992. Transnationalism: A New Analytical Framework for Understanding Migration. New York: New York Academy of Sciences.

Guarnizo, L. E. 2003. “The economics of transnational living.” International Migration Review 37(3): 700-723.

Hannam, K., M. Sheller, and J. Urry. 2006. "Editorial: Mobilities, Immobilities and Moorings." Mobilities 1(1): 1-22. 
Hannerz, U. 1996. Transnational Connections: Culture, People and Places. London: Routledge.

Hassner, P. 2002. "Fixed borders or moving borderlands?: a new type of border for a new type of entity." In Europe Unbound: Enlarging and Reshaping the Boundaries of the European Union, edited by J. Zielonka, 38-50. London: Routledge.

Hyndman, J. 2012. "The geopolitics of Migration and Mobility." Geopolitics 17(2): 243-255.

Jansen, A. 2013. "Mobility Regimes and Borderwork in the European Communities." Mobilities 8(1): 35-51.

King, R., R. Skeldon, and J. Vullnetari. 2008. "Internal and International Migration: Bridging the theoretical divide.” Working Paper, 52. Centre for Migration Research: Sussex.

International Labour Organization. 2006. Labour and social issues arising from problems of cross-border mobility of international drivers in the road transport sector, Report for discussion at the Tripartite Meeting on Labour and Social Issues arising from Problems of Cross-border Mobility of International Drivers in the Road Transport Sector (Geneva: ILO). Accessed June 29, 2013 http://www.ilo.org/wcmsp5/groups/public/---ed_dialogue/ sector/documents/meetingdocument/wcms_161667.pdf $/$.

Marchetti, S., and Venturini, A. 2013. "Mothers and Grandmothers on the Move: Labour Mobility and the Household Strategies of Moldovan and Ukrainian Migrant Women in Italy." International Migration doi: 10.1111/imig.12131. 
Marcu, S. 2009. "The Geopolitics of the Eastern Border of the European Union: The Case of Romania-Moldova- Ukraine.” Geopolitics 14(3): 409 -432.

Meinhof, U.H. 2002. "Introducing Borders, Networks, Neighbourhoods: Conceptual Frames and Social Practices." In Living with Borders: identity Discourses on East-West Borders in Europe, edited by U.H. Meinhof, 1-15. Aldershot: Ashgate.

Michalon, B., and M. Nedelcu. 2010. "Introduction. Histoire, constantes et transformations récentes des dynamiques migratoires en Roumanie." Revue d'Études Comparatives Est-Ouest 41(4): 6-27.

Ministry of Employment and Social Security, Spain 2005. Royal Decree 2393/2004, of 30 December, approving the Regulations of Organic Law 4/2000 of 11 January on the rights and freedoms of foreigners in Spain. Accessed December 30, 2013 http://extranjeros.empleo.gob.es/es/NormativaJurisprudencia/Nacional/RegimenExtranjeria/R egimenGeneral/documentos/RD2393-04.pdf /.

Morokvasic, M. 2004. “'Settled in Mobility': Engendering Post-Wall Migration in Europe.” Feminist Review 77(1): 7-25.

Newman, D. 2006. "Borders and Bordering: Towards an Interdisciplinary Dialogue." European Journal of Social Theory 9(2): 171-186. 
Paasi, A. 2009. "Bounded Spaces in a 'Borderless World': Border Studies, Power and the Anatomy of Territory." Journal of Power 2(2): 213-234.

Pijpers, R., and M. Van der Velde. 2007. "Mobility across Borders: Contextualizing Local Strategies to Circumvent Visa and Work Permit Requirements." International Journal of Urban and International Research 31(4): 819-835.

Portes, A., L-E. Guarnizo, and P. Landolt. 1999. "The Study of Transnationalism: Pitfalls and Promise of an Emergent Research Field.” Ethnic and Racial Studies 22 (2): 217-237.

Recchi, E., and A. Favel. 2009. Pioneers of European Integration: Citizenship and Mobility in the EU. Cheltenham: Elgar.

Rumford, C. 2007. “Does Europe have cosmopolitan borders?” Globalizations 4(3): 327-339.

Rumford, C. 2006. "Borders and rebordering." In Europe and Asia Beyond East and West: Towards a New Cosmopolitanism, edited by G. Delanty, 181-192. London: Routledge.

Sandu, D. 2006. Living abroad on a temporary basis. The Romanians and the economic migration: 1990-2006. Bucharest: Open Society Foundation.

Scott, J., and H. Van Houtum. 2009. "Reflections on EU territoriality and the 'bordering' of Europe.” Political Geography 28(5): 271-273.

Scott, J. 2006. EU Enlargement, Region Building And Shifting Borders of Inclusion And Exclusion. Aldershot: Ashgate. 
Scuzzarello, S., and C. Kinnvall. 2013. "Rebordering France and Denmark Narratives and Practices of Border-Construction in Two European Countries." Mobilities 8(1): 90-106.

Sheller, M., and J. Urry. 2006. “The new mobilities paradigm.” Environment and Planning A 38(2): 207-226.

Stanek, M., and R. Hosnedlova. 2012. "Exploring transnational practices of Ukrainian migrants in Spain," Economics and Sociology 5(1): 62-73.

Urry, J. 2007. Mobilities. Cambridge and Malden, MA: Polity Press.

Van Houtum, H., O.T. Kramsch, and W. Zierhofer. 2005. Bordering Space. Aldershot: Ashgate.

Van Houtum, H., and A. Strüver. 2002. "Borders, strangers, doors and bridges." Space \& Polity 6(2): 141-146.

Van Houtum, H. 2000. “An overview of European geographical research on borders and border regions.” Journal of Borderlands Studies 15(1):57-83.

Van Houtum, H. 1999. "Internationalization and mental borders." Tijdschrift voor Economische en Sociale Geografie 90(3): 329-335.

Van der Velde, M., and T. Van Naerssen. 2011. "People, borders, trajectories: an approach to cross-border mobility and immobility in and to the European Union." Area 43(2): 218-224. 
Verstraete, G. 2001. "Technological frontiers and the politics of mobilities." New Formations (43): 26-43.

Vertovec, S. 2007. "Circular Migration: the way forward in global policy?" Working Paper. International Migration Institute James Martin 21st Century School. University of Oxford, paper 4 .

Viruela, R. 2011. "The Romanian Migrants in Spain. An Exceptional Migratory Flow." International Review of Social Research 1(1): 31-59.

Wallace, W. 2002. "Where Does Europe End? Dilemmas of Inclusion and Exclusion." In Europe Unbound: Enlarging and Reshaping the Boundaries of the European Union, edited by J. Zielonka, 78-94. London: Routledge. 